\title{
Introduction:
}

\section{FOUR SCANDALS, THREE REFORMS}

Virtually every urban police department in the United States has experienced both organized corruption and a major scandal over that corruption.' ${ }^{1}$ While a complete census of corrupt urban police departments has never been taken, the published evidence is extensive enough to justify this assertion. ${ }^{2}$ The assertion may even be true for just the period since World War II. There is almost no evidence, however, regarding the consequences of corruption scandals in urban police departments. Given the frequent repetition of corruption scandals in a number of police departments, it seems reasonable to assume that most corruption scandals are not followed by permanent reform. Yet some police departments have experienced successful reforms. The problem this study

1. William J. Chambliss, "Vice, Corruption, Bureaucracy and Power," The University of Wisconsin Law Review, Vol. 1971, pp. 1150 1170. See also Antony Simpson, The Literature of Police Comption: Volume 1. A Guide to Bibliography and Theory (New York: The John Jay Press, 1977); Ralph Lee Smith, The Tarnished Badge (New York: Thomas Y. Crowell and Co., 1965); and Robert H. Williams, Vice Squad (New York: Thomas Y. Crowell, 1973). Even the Metropolitan London Police (Scotland Yard) have experienced corruption, scandal, and reform in recent years. See Barry Cox, John Shirley, and Martin Short, The Fall of Scotland Yard (London: Penguin Books, 1977).

2. The police departments subjected to scandal over organized corruption include, for example, Los Angeles, Denver, Seattle, San Francisco, Kansas City, East St. Louis, Chicago, Indianapolis, Louisville, Buffalo, Philadelphia, Miami, and Boston. A survey of corruption scandals collected by a national clipping service in the summer of 1973 also showed scandals in small towns and rural sheriff's departments. (Internal memorandum, the Police Foundation.) 
only begins to address is why some and not other scandals are followed by successful reform.

As a first step in distinguishing the conditions of successful and unsuccessful post-scandal reform, three police departments were selected for study on the basis of their reputations for successful reform: New York City; Oakland, California; and Newburgh, New York. A fourth case, pseudonymous "Central City," was selected just after a scandal occurred, because it could be studied in the process of post-scandal reform rather than historically. ${ }^{3}$ As it happened, Central City was apparently a case of unsuccessful reform, but its failure is very useful in illuminating the conditions of success in the other three departments.

All four of the police departments had experienced corruption for many years before the major scandal occurred that is studied here. Two of them, New York and Central City, had also suffered earlier major scandals in relatively recent years. But only one, New York, had been previously subjected to repeated and unsuccessful attempts at reform. What follows is a summary of the history of corruption and scandal in each of the four police departments studied.

3. The use of a pseudonym to identify Central City was a condition of the grant of access to confidential sources there. The salient differences between Central City and the other case studies are as follows:

Differences among the Four Case Studies

\begin{tabular}{|c|c|c|c|c|}
\hline Differences & $\begin{array}{c}\text { New York } \\
\text { Cing }\end{array}$ & $\begin{array}{c}\text { Central } \\
\text { Cing }\end{array}$ & $\begin{array}{l}\text { Oalland, } \\
\text { Calif. }\end{array}$ & $\begin{array}{l}\text { Newburgh, } \\
\text { N.Y. }\end{array}$ \\
\hline $\begin{array}{l}\text { Population* } \\
\text { Police Dept. }\end{array}$ & $8,000,000$ & 750,000 & 376,000 & 26,200 \\
\hline $\begin{array}{l}\text { Size* } \\
\text { Years under }\end{array}$ & 30,000 & 1,100 & 700 & 70 \\
\hline $\begin{array}{l}\text { Study } \\
\text { Form of } \\
\text { Government }\end{array}$ & $\begin{array}{l}\text { 1970-75 } \\
\text { Strong } \\
\text { Mayor }\end{array}$ & $\begin{array}{l}\text { 1963-75 } \\
\text { Strong } \\
\text { Mayor }\end{array}$ & $\begin{array}{l}1952-60 \\
\text { Council- } \\
\text { Manager }\end{array}$ & $\begin{array}{l}1970-75 \\
\text { Council- } \\
\text { Manager }\end{array}$ \\
\hline $\begin{array}{l}\text { Geographic } \\
\text { Region }\end{array}$ & Northeast & Midwest & West Coast & Northeast \\
\hline
\end{tabular}




\section{NEW YORK}

The continuing corruption of law enforcement in New York City from colonial times to 1971 has been well documented. 4 Although New York police have used their official powers to protect or commit every crime from burglary to election fraud and murder, the main source of police corruption there has always been the purveyors of illegal pleasures: prostitution, alcohol, gambling, and, in recent years, narcotics. The first major scandal over police protection of vice activities occurred in 1894, when the Lexow Committee of the New York State Senate conducted hearings on police corruption at the request of a crusading investigative clergyman, Charles Parkhurst. The testimony of an endless procession of gamblers, prostitutes, madams, and policemen painted a picture of a police department thoroughly corrupted, existing solely for the personal profit of its members. The hearings assured the election of a reform mayor who appointed Theodore Roosevelt head of the police department. ${ }^{5}$ Roosevelt instituted some reform policies, but corruption persisted in a more sophisticated, less visible manner. ${ }^{6}$ Roosevelt went on to other offices, and corruption eventually returned to "normal."

Similar scandals and attempts at reform have occurred in New York in almost regular twenty-year cycles. The Curran Committee in 1911, the Seabury Report in 1932, the investigation of gambling "czar" Harry Gross in 1951, and the Knapp Commission hearings in 1971 all exposed widespread and highly organized police corruption. ${ }^{7}$ Every one of these scandals was apparently associated with the appointment of a new police

4. See James F. Richardson, The New York Police: Colonial Times to 1901 (New York: Oxford University Press, 1970); and Gerald Astor, The New York Cops: An Informal History (New York: Scribner's, 1971).

5. Lincoln Steffens, Autobiography (New York: Harcourt Brace and Company, 1931), Chapters X-XI.

6. Lincoln Steffens, The Shame of the Cities (New York: McClure, Phillips and Co., 1904; Hill and Wang, 1957), p. 206.

7. City of New York, Commission to Investigate Allegations of 
commissioner who was expected to reform the department. But however successful their reforms may have been in the short run, none of the earlier reform executives succeeded in reforming the New York City Police Department on a lasting basis.

Perhaps the most intensive unsuccessful effort at reform was the most recent one, in the aftermath of the scandal over gambler Harry Gross' payoffs to hundreds of police officers. ${ }^{8}$ A succession of reform commissioners tried to control corruption by tightening the central control over the department. Rigid bureaucratic procedures were established for almost every phase of police activity, with a heavy emphasis on maintaining written records of every official action. Procedures were particularly strict in the enforcement of vice and gambling laws. But the paper work failed to prevent corruption, and was twisted to serve as a mechanism of defense in case of corruption investigations. Moreover, it was understood that while the top officials would punish officers foolish enough to be caught at corruption, "the brass" did not really want to know about any corruption that may have been going on. ${ }^{9}$ In fact, the reluctance to initiate investigations helped to precipitate the most recent scandal.

In 1966, an officer named Frank Serpico was invited to join a gambling "pad": a group of officers in a plainclothes gambling squad who were paid off by a gambler. Serpico refused to join, as he had refused similar offers in the past. At the suggestion of a fellow officer who was assigned to the Department of Investigation (the city's anti-corruption unit), Serpico told the

Police Corruption and the City's Anti-Corruption Procedures, Commission Report (New York: George Braziller, 1973), pp. 61-64.

8. See Norton Mockridge and Robert H. Prall, The Big Fix (New York: Henry Holt, 1954).

9. Allan N. Kornblum, "The Moral Hazards: Strategies for Honesty and Ethical Behavior in the New York City Police Department" (Ph.D. dissertation, Princeton University, 1973); interview with William P. McCarthy, former First Deputy Commissioner of the New York City Police Department, January, 1975. 
captain in charge of that department's police detail about the existence of the "pad." The captain, according to Serpico, warned that such accusations could result in his being found in the East River. Serpico then tried, successively, to interest the commander of the police area in which he worked, the First Deputy Police Commissioner, the mayor's assistant for police matters, and the Commissioner of Investigation. None of these officials took any action in response to Serpico's allegations. Finally, in late 1967, the area commander initiated an investigation of the pad identified by Serpico. Dissatisfied at the failure of high officials to undertake more general efforts against police corruption, Serpico and several other police officers supplied information to the New York Times that was published in April of $1970 .^{10}$

In response to the Times stories, the mayor appointed a committee to investigate the allegations. The committee included the district attorney of Manhattan and the police commissioner, both of whom had responsibility for controlling police corruption. After the police commissioner publicly attacked the Times stories for using unreliable sources, the committee recommended that an "independent" body be created to investigate the allegations. The mayor then appointed a "blue ribbon" Commission to Investigate Allegations of Police Corruption and the City's Anti-Corruption Procedures, chaired by former Assistant District Attorney Whitman Knapp. ${ }^{11}$ The police commissioner resigned before the Knapp Commission launched its investigation, and a new commissioner, Patrick V. Murphy, was quickly appointed.

10. David Burnham, "Graft Paid to Police Here Said to Run into Millions." New York Times, April 25, 1970, p. 1. See also Peter Maas, Serpico (New York: Viking, 1973); City of New York, Commission Report (n. 7 above), pp. 196-204; and David Burnham, The Role of the Media in Controlling Corruption (New York: The John Jay Press, 1976).

11. It is interesting to note that one of the Commission members, Cyrus Vance, later became Secretary of State, while another, Joseph Monserrat, was later convicted on corruption charges himself in connection with the New York City Board of Education. 
Murphy had been a New York City police commander for almost twenty years, serving most of that time in such corruption-free units as the police academy. He had served as the reform chief of the Syracuse (New York) Police Department after a gambling corruption scandal there, and he had also headed the Washington, D.C. and the Detroit police departments. When he returned to New York in October of 1970, the Knapp Commission investigation was just getting under way. Thus, Murphy was put in the rather awkward position of being a reformer before the corruption scandal had fully unfolded. Not until October of 1971 , when the Knapp Commission held its public hearings, was the full extent of police corruption publicly disclosed. In the year between his appointment and the commission hearings, Murphy struck a difficult balance between demonstrating strong policies against corruption and not antagonizing the rank and file and their public supporters who claimed that police corruption was minor and isolated.

The Knapp Commission hearings destroyed the police union's argument that police corruption was confined to a few "rotten apples" in an otherwise healthy barrel. ${ }^{12}$ While the union president labeled the Knapp Commission evidence "a tale concocted in a whorehouse," the testimony of corrupt police officers and the tape-recorded evidence they had gathered after being "turned" to work as undercover agents for the commission provided overwhelming documentation of highly organized corruption in almost every area of the department. Chairman Knapp called upon Murphy to "bite the bullet" and acknowledge the existence of pervasive corruption - which, in effect, Murphy did. And while Murphy had already punished a number of commanders for being too lax with corruption, the most severe anti-corruption policies were not adopted until a new deputy commissioner for vice enforcement was ap-

12. City of New York, Commission Report (n. 7 above), pp. 5-6. See also Lawrence W. Sherman, ed., Police Corruption (Garden City, N.Y.: Anchor Books, 1974), pp. 6-12. 
pointed just before the Knapp hearings. The hearings provided the external pressure necessary to justify, both internally and externally, draconian measures against corruption.

In August of 1972, the Knapp Commission recommended that the governor appoint a Special Deputy State Attorney General to supersede the five New York City district attorneys in all investigations of corruption in New York's criminal justice system. The special prosecutor took office in September of 1972. The Knapp Commission had operated on a minuscule budget with a few borrowed federal investigators, but the special prosecutor's office was well funded and well staffed. Nonetheless, most of the police corruption cases ultimately prosecuted by that office were developed either by the Knapp Commission or by police department anticorruption squads. This point is important for the comparability of the four police departments studied here, since only New York had a special anti-corruption prosecutor during the reform period and beyond. While the existence of a special prosecutor may have had some deterrent effect on corruption, the only difference it made in the investigation and prosecution of police corruption was that the police department corruption investigators were able to obtain subpoenas and access to a grand jury more easily than with the district attorneys. ${ }^{13}$

After two and a half years of drastic reforms and almost daily headlines, Murphy resigned in April of 1973. His handpicked successor, Donald Cawley, served only nine months, resigning when a new mayor was elected. Another high official of Murphy's administration, Michael Codd, was appointed commissioner in January of 1974. Both Cawley and Codd continued Murphy's anti-corruption policies apparently without major changes.

From all indications, the most recent episode of scandal and reform in the New York City Police Department has reduced police corruption to a very minimal level.

13. Interview with John Guido, Commander of the Internal Affairs Division, New York City Police Department, 1975. 
"Pads" and other highly organized forms of corruptionn seem to be virtually extinct. Six years after the Knapsp Commission hearings, corruption no longer appears tto be widespread. Evidence presented in subsequent chapters covers only the years up to 1975 , but other indlicators of a high level of integrity could still be found iin 1977. A film producer, for example, observes that it is no longer necessary to pay off the police when filminig location shots on the streets of New York. ${ }^{14}$ While skepptics may find it difficult to believe that law en forcememt in New York is organizationally honest, all of the availaable evidence points to that conclusion.

\section{OAKLAND}

California police departments have long enjoyed a reputation for honesty far superior to that of their eastiern counterparts. While that reputation may be deeserved today, it was certainly not valid thirty years agco. In the years just after World War II, California policingg was no less subject to control by corrupt political influaences and racketeers than policing elsewhere in the naation. ${ }^{15}$ The Oakland Police Department in 1954 was noo exception to that rule.

A port city and a terminus of major railroads, Oakkland has always had a large population of unattacheed males providing a prime market for vice services. Thne vice services, in turn, once provided a prime market foor police extortion. One Oakland officer recalled his faather's tales of police shaking down prostitutes early in the century. Another described the systematic robberry

14. "TV Producers Are Nibbling at the Big Apple," New Yorlok Times, July 31, 1977, p. D21. See also "After Knapp, the Police Seenm

Less Corruptible," New York Times, July 4, 1976, Section 4, 4.

15. State of California, Special Crime Study Commission on Or-rganized Crime, Combined Reports (Sacramento: California Statete Board of Corrections, 1950), and Final Report (Sacramento: Califor-rnia State Board of Corrections, 1953); Joseph Gerald Woods, "There Progressives and the Police: Urban Reform and the Professionaliza-dtion of the Los Angeles Police" (Ph.D. dissertation, University of f California at Los Angeles, 1973). 
by police of black shipyard workers every Friday night after the workers had been paid and had cashed their checks in the local bars.

While police corruption was not as diverse in Oakland as it was in New York or other larger cities, it was apparently as pervasive and well organized. Fewer types of corruption may have been practiced, but the vice corruption that did exist seems to have been tightly controlled at the precinct level.

A major police corruption scandal occurred just after the turn of the century, but the police escaped intensive public scrutiny for the next fifty years. Earl Warren built a career on his prosecutions of official corruption in Alameda County in the 1920 s and ' 30 s, but he left the Oakland Police Department largely unscathed. His convictions of Oakland officials did lead to the adoption of a city manager form of government in 1931, which insulated the police somewhat from corrupt political control. But despite this reform, a city council member was allegedly arranging for paid police protection of gambling operations as late as $1953 .^{16}$

The year 1953 was a difficult one for the Oakland Police Department. Two officers were accused of committing a burglary, another was charged with sexually harassing a woman, and a third was named as a bagman for gambling payoffs. ${ }^{17}$ Yet all of this produced what we shall later define as a "little scandal": a brief, shallow reaction of public disapproval. After reporting the corruption stories as they occurred, the major newspaper probed no further. The events were serious enough to have been the subject of a "big" scandal, but no big scandal occurred.

A new city manager, Wayne Thompson, was appointed in late 1954. His predecessor had run a "caretaker" style of administration for twenty years, generally deferring to local business interests in providing minimal city services and minimal property taxes. Thompson

16. Oakland Tribune, April 7, 1953.

17. Oakland Tribune, January 16, January 28, and April 17, 1953. 
had grown up in Oakland, and had been city manager of nearby Richmond since the end of World War II. He had ambitious plans for Oakland, one of which was reforming the police department. But in order to take the drastic action necessary for fighting police corruption, Thompson felt that a public justification was needed. That is, he decided that his solution could only be imposed after the problem of police corruption had been impressed upon the public. ${ }^{18}$

After only a few months in office, Thompson found an opportunity to dramatize the weaknesses of the police. A police sergeant tried to extort a payment from a hardware store owner who had been drinking prior to a minor traffic accident. When the extortion victim refused to pay, he was abducted at night and taken into the Oakland hills by two police officers who beat and robbed him. When he tried to file a complaint at the local precinct station, the extortion victim was subjected to further harassment. The chief's office eventually investigated the case, but little came out of the investigation for several months. In early 1955 , a reporter caught wind of the story and called Thompson before publishing it. Thompson called a press conference, publicly rebuked the police chief, and ordered that all future complaints of police misconduct be relayed immediately to the city manager's office. ${ }^{19}$

The district attorney soon called several police officers before a grand jury to testify in the extortion and cover-up case. Meanwhile, another corruption case was disclosed in the newspapers, this one alleging that detectives had taken gifts from burglars in jail awaiting trial. ${ }^{20}$ The prosecutor seized on this case as well, and a "big" scandal was underway. Thompson asked the publisher of the Oakland Tribune to keep police corruption in the headlines. ${ }^{21}$ For over two weeks, the police were front-

18. Interview with Wayne Thompson, May 9, 1975.

19. Oakland Tribune, January 4, 1955.

20. Oakland Tribune, January 15, 1955.

21. Interview with Wayne Thompson, May 9, 1975. 
page news. When there was no new development in the corruption cases to report, a "background" story on management problems in the police department appeared. The police chief went on sick leave shortly after the scandal began, and resigned a few weeks later. ${ }^{22}$

Thompson immediately appointed Captain Wyman Vernon as the reform chief. A University of California graduate who had joined the Oakland Police Department during the Depression, Vernon had served under Thompson previously as chief of the Richmond Police Department on a one-year leave from Oakland. Vernon had also been a reformer in Richmond, reshaping an old-fashioned police operation into a modern bureaucracy. As head of the Traffic Division in Oakland, Vernon had been largely isolated from the primary forms of police corruption. Yet he knew that corruption was extensive, and he moved quickly to control it. His first act was to appoint an "inspector general" responsible for investigating all police misconduct. The department was given notice that the old rules of the game were gone, and that all misconduct would be punished rather than covered up.

Within a year, most forms of police corruption had disappeared. A few organized forms of corruption persisted up to 1959, Vernon's final year in office. But the gambling and prostitution payoffs-which had never been disclosed publicly during the scandal-apparently ceased during Vernon's first year in office. Many old officers retired, and a "new breed" of Oakland officer was recruited from across the nation. The police code of silence was broken by a few officers who turned in other officers for misconduct. Thompson and Vernon took such a strong stance against corruption that reform spread beyond the police department into the general political culture of the community. ${ }^{23}$ Some city officials

22. Oakland Tribune, January 22-February 8, 1955.

23. Lawrence W. Sherman, "Corruption Scandals and Political Change: Police and Civic Culture" (paper presented to the 1977 Annual Meeting of the American Political Science Association, 
were reportedly scared out of their own corrupt activities by fear of Vernon's spies. Enforcement of gambling laws became so rigid that even church bingo games were forced to close.

All of Vernon's successors have continued his policies for controlling corruption. The character of the Oakland Police Department today remains basically that which Vernon shaped in 1955. The Oakland police have been studied by major scholars of the police and subjected to intense public criticism regarding their relations with blacks and radicals. ${ }^{24}$ But there have been almost no allegations of widespread, organized corruption in the Oakland Police Department since 1955.25 The reform of the Oakland police is one of the most lasting of any American police agency.

\section{NEWBURGH}

Unlike New York and Oakland, Newburgh had always had close ties between the dominant political party and police corruption. Such ties seemed to disappear in New York after the Harry Gross scandal nearly led to the indictment of a mayor, and in Oakland the nonpartisan system of government kept corrupt ties of police to politicians on a personal rather than a party level. While Newburgh has long had a city manager form of government, political parties have never been banned from local politics. Years of control over the city and county by the same party (Republican) once meant that every police official in Newburgh owed his job to-or had purchased it from-the party. The civil service rules for appointment and promotion notwithstanding, patronage was the real police personnel system. ${ }^{28}$

Washington, D.C.).

24. James Q. Wilson, Varieties of Police Behavior (Cambridge, Mass.: Harvard University Press, 1968), pp. 263-266.

25. Only one former Oakland officer interviewed claimed that organized vice corruption persisted after mid-1955.

26. Wilson, Varieties of Police Behavior, p. 244. 
Ever since its heyday as a transport center, Newburgh had been the center of vice activities in Orange County. Prostitution was centered in a locally famous brothel patronized by judges and other politicians. The brothel and the several gambling operations in town paid the party for protection from the police. They also made small courtesy payments directly to the police. In the late 1960s, the local economy seriously deteriorated, and the vice industry changed as well. The brothel was closed down by a state police raid and razed by urban renewal bulldozers. Narcotics dealing mushroomed in the large black community, with no tribute from the dealers paid to the party. The police took advantage of the national narcotics scare to "crack down" on dealers-stealing their drugs and cash while making arrests. Police burglary of businesses, the form of corruption that precipitated the scandal, also appears to have begun only in the early 1970 s after the appointment of a new chief. ${ }^{27}$

Allegations of police thefts from narcotics dealers were first made public in late 1970. Like the disclosures of police corruption in Oakland in 1953, however, the allegations of corruption in Newburgh in 1970 only produced a little scandal. One citizen group demanded an investigation, but most of the public seemed disinterested. The little scandal may have been a green light for more police burglary and thefts from narcotics dealers, for the frequency of such crimes (as was later discovered) increased substantially.

The Newburgh police stepped over the limits of safe corruption when they burglarized the local outlet of a large national corporation, Sears, Roebuck and Company. A Sears employee happened to observe police officers taking merchandise out of the store late at night, and reported the theft to the Sears security staff. The regional security director for Sears demanded that

27. Interview with Deputy Police Commissioner Thomas Wohlrab, February, 1976; but see Newburgh Evening News, January 16, 1973, reporting burglaries as early as 1965 . 
the chief arrest the officers responsible for the theft. The chief, who had been the ringleader of the burglary, reported that the charge was unfounded; all his officers, he said, had been elsewhere at the time. ${ }^{28}$ The Sears official then asked the state police to investigate. One officer "cracked" under interrogation, and others quickly joined in giving evidence in exchange for leniency. The investigation quickly spread beyond the Sears burglary to encompass several other burglaries and thefts from narcotics dealers. The district attorney, though tied to the Party, had no choice but to prosecute fifteen of the department's sixty-four officers (23 percent); he resigned midway through the prosecution, and was later rumored to be under federal investigation himself. All fifteen officers were convicted, and the chief was sentenced to eleven years in "Sing Sing" (Ossining Correctional Facility). ${ }^{29}$

The indictments of the police were handed down in early 1972, and the trials were not completed until later that year. The department was left in a state of uncertainty, not knowing if further indictments or a more wide-ranging investigation would be forthcoming. The deputy chief served as acting chief, playing a caretaker role. In November of 1972, a reform slate of Democrats gained control of the city council and decided to change the managerial structure of the police department. Instead of having a civil service chief appointed from the ranks (at about $\$ 12,000$ per year), the new council created an untenured position of police commissioner (at $\$ 25,000$ per year) to be appointed at the pleasure of the city manager. Two deputy police commissioners (at $\$ 18,000$ per year) were to be appointed at the pleasure of the police commissioner. This structural change allowed "outsiders" to be appointed to run the police department.

The first police commissioner was appointed in early 1973. A former assistant district attorney of Orange

28. Interview with Thomas Wohlrab, February, 1976.

29. Newburgh Evening News, March 2, 1973. 
County, he was only an "outsider" in the sense that he was not a career police officer. In keeping with his background, he devoted most of his time to investigating past corruption in the department. After a year of "mopping up," he charged a few officers with violations of administrative rules, and then he resigned. He did not introduce new policies and he did not try to "reform" the department in the sense in which the word is used in this study. ${ }^{30}$

Not until the spring of 1974, a full two years after the scandal began, was a reform police executive appointed. James Taylor, the second police commissioner, was a true outsider. A graduate of the Michigan State University School of Police Administration, Taylor had been a police official in several midwestern departments, most recently in a small city outside Minneapolis. He had had little contact with police corruption in his previous jobs, but he had a plan for controlling corruption in Newburgh. After hiring two former colleagues (also from the midwest) as deputy police commissioners, Taylor established a close surveillance over the department. At the same time, he brought the department into the twentieth century, implementing for the first time in the department's history such basic procedures as compiling full crime statistics. Taylor felt so confident about his control of the department that, unlike the other reform police executives in this study, he requested that his department be included.

Using the same approach and types of sources as in the other cities, I could not find reports of police corruption in Newburgh subsequent to the 1972 scandal. Many sources described the department as still being "shell-shocked" from the scandal as late as 1975 . Whatever the reason, corruption appeared to be nonexistent at the time Taylor was appointed. And from all indications, there was still no corruption five years after the scandal. Taylor was promoted to city manager in late

30. Interview with former Police Commissioner James Taylor, October 8, 1975. 
1975, but he continued to keep tight control over the police department through a former deputy commissioner who replaced him as commissioner. Indeed, some critics complained that Taylor's control was too tight, and the department was ready to move on to a more participatory, less authoritarian style of management. The premise of that critique was that the Newburgh Police Department was a basically honest organization that could be trusted not to abuse its authority-a far cry from the corrupt organization of the early $1970 \mathrm{~s}$.

An important aspect of the long-term reform of the Newburgh police was the removal of the department from control by the Republican Party. The voters helped speed this development by electing Democrats to the city council. But Taylor insured against a return of "machine" control by eliminating the leadership of the party through federal investigations. At Taylor's urging, the (Republican) U.S. Attorney launched a broad investigation of (Republican) political corruption in Orange County. Two top political leaders died just before they were to be indicted, it was rumored, one of them reportedly by suicide. The county Republican Party chairman was indicted, and he was convicted in 1976 on charges of fixing a criminal case.

\section{CENTRAL CITY}

Central City has a long history of police corruption and scandal. Since the turn of the century, over one hundred police officers have been accused by name of corrupt activities. However, only five have ever been convicted on criminal charges. Prosecutors, judges, and juries have shown repeated tolerance of police corruption. Mayors and political leaders have fostered police corruption as a means of insuring substantial "contributions" to the party from vice operations. Politicians have even run vice operations themselves; one former mayor was alleged to have financed a brothel. While one party was never in control long enough to develop a "machine," the relationship of police corruption to polit- 
ical control changed little from administration to administration; only the cast of characters changed. As a former mayor reportedly said: "The purpose of the police is to give the graft to the Republicans when the Republicans are in power and to the Democrats when the Democrats are in power."

Since World War II, Central City has had a number of little scandals over police corruption. The first big corruption scandal occurred in 1963, while the Democrats were in power. A federal gambling raid uncovered a list of names of police officers whom the gambling operation paid for immunity from arrest. After a year of jurisdictional disputes by the federal and local prosecutors, the evidence finally resulted in the local indictment of twenty-two active or retired police officers. The indictments produced a big scandal, but the community was hardly united in disapproval of the defendants. A citizens' group was formed to collect charitable donations for the defendants' families, and several defendants were given jobs in the public school system. One defendant was convicted, but charges against the others were dropped when the key witness refused to testify. The cleared defendants were reinstated as police offcers with back pay. Corruption had apparently ceased while the charges were pending, but it gradually returned to its pre-scandal scope after the charges were dropped.

The Republicans gained power in 1968 and reportedly took control of the vice payoffs. Little of the vice money went to police officers, but all officers were pressured to ignore the crimes of those who had paid the party for protection. In return, the party tolerated minor "free-lance" forms of corruption by the police: payoffs to allow illegal parking, kickbacks from towtruck drivers called to accident scenes, shakedowns of street prostitutes and tavern owners violating liquor laws, thefts from arrested suspects, and bribes for changing testimony at criminal trials to "fix" the outcome. In the early 1970 s, the police reportedly began 
selling protection to the rapidly expanding narcotics industry, but it is unclear whether these arrangements were "free-lance" or coordinated through party officials.

An interesting feature of the linkage between police corruption and politics in Central City is that the mayor was not a participant in any aspect of that linkage and was apparently ignorant of its existence. Diverse sources agree on this point, and the mayor's own actions prior to the big scandal support it. In 1972, the mayor heard hints of corruption among high police officials, and he created a little scandal by publicly asking those officials to submit statements of their net worth. The police union aroused public sentiment against this move, and the mayor withdrew his order. He then asked the chief to establish a new system of internal corruption controls, but the chief ignored the request. A rumored federal investigation of police corruption was also reported to have been dropped at that time.

The local newspaper, however, began to look into police corruption. By mid-1973, a team of investigative reporters had found a number of sources within the police department who provided detailed information about corruption activities. Friction between the county police and the city police encouraged the former to "pump" city police prisoners in the county jail for information about corruption in the city police. By early 1974, the reporters had gathered enough allegations confirmed by independent sources to publish a series of front-page stories on police corruption. The result was a major scandal.

The mayor, who was running for statewide office that year, quickly asked the chief of police, the deputy chief, and the public safety director to resign. The deputy retired from the department, but the chief reverted to his civil service rank of major because he had not served enough years to be eligible for a pension. The mayor appointed a special police investigating unit to follow up on the newspaper's allegations and report directly to 
him. This unit was dubbed the "Truth Squad," since it defined its mission as determining the truth of the newspaper stories. For the most part, the unit found that the stories were untrue, or at least lacking in evidence sufficient for criminal prosecution. A few minor indictments were obtained against low-ranking officers, but none of the allegedly corrupt top police officials were ever indicted.

The mayor decided to appoint an outsider as police chief, but was restricted by the city charter to candidates with a bachelor's degree in police administration and ten years of supervisory experience in law enforcement. Only one local candidate fit the requirements, and there was no time for undertaking a national search. The mayor appointed a retired federal police official who was teaching criminal justice at a local college. The new chief was greeted by the press with enthusiasm, but the "honeymoon" did not last for long. The press never challenged the reform chief's integrity or vigor in investigating corruption, but it did attack him for failing to embrace the rebellious police officers who had provided information to the press. The chief's view is that he made reasonable overtures to the rebellious officers, but they refused to provide the specific information required for taking corruption cases to a grand jury.

The scandal continued for almost a year. The district attorney, a crony of the party leaders, indicted two reporters for allegedly attempting to bribe a police officer in the course of their investigation. The voters turned the district attorney out of office in the fall election, and the new district attorney dropped the charges against the reporters. The mayor lost his home county in his unsuccessful bid for statewide office, even though the newspaper responsible for creating the scandal endorsed his candidacy. Both the mayor and the reform chief remained in office for one more year, until the mayor retired and a Democratic mayor was elected.

Corruption declined substantially in Central City during the first year of the reform administration. Whether 
this change is attributable to the scandal or to the reform policies is an issue we shall examine in detail later on. The important point here is that the policies adopted by the reform chief to control corruption differed substantially from those policies adopted by the other three reform chiefs studied. Although the evidence is far from conclusive, it is plausible to argue that the Central City experience in 1974-75 was a case of unsuccessful reform. The funding for our research project came to an end before enough time could elapse to see if corruption would expand as the effects of scandal wore off. Based on the analysis of corruption control policies offered here, a prediction can be made that organized corruption will soon flourish again in the Central City Police Department. The former mayor agrees with this assessment, citing the resilience of the corrupt relationships among police and criminals. The main reason for the predicted failure of reform in Central City is that adequate systems for collecting information about police corruption were not established. Without such information, police corruption probably cannot be controlled. 